DOI: $10.24143 / 2073-1574-2021-3-14-22$

УДК [629.5.017.3:621.396.96]:656.61.052.484

\title{
MULTIFUNCTIONAL SIMULATOR FOR PROVIDING SHIP WITH DATA ON MANEUVERABILITY
}

\author{
V. A. Dorovskoy ${ }^{1}$, A. V. Degtyrev ${ }^{2}$, N. P. Smetuch ${ }^{1}$, A. A. Zinchenko ${ }^{1}$ \\ ${ }^{1}$ Kerch State Maritime Technological University, \\ Kerch, Russian Federation \\ ${ }^{2}$ GMZ Ship Management CO SA, Beirut, Lebanon
}

\begin{abstract}
The article presents the research analysis on the ship safety. It has been found out that due to the lack of a methodology for planning an algorithm for the maneuvering control system, there is no concept of solving technological problems or any understanding of what data are needed to perform the work. Despite the cybernetic devices and programs perform some part of the work and prepare the necessary data, the skipper does not understand how the device generates them. The task was to create a prototype that could allow to get data on the ship maneuverability. After the initial stage of training has been passed the skills should be obtained, which further will transform into the passive and stable abilities. The created hardware and software package allows implementing the concept of the guaranteed safety of maneuvering control in piloting vessels due to improving the methods of forming sustainable skills and bringing it to the automation level. It was recommended to use a simulator with visualization, to introduce the new algorithms of controlling the ship propulsion in the area of responsibility by coastal and to develop the recommendations on divergence, new training methods for pilots on shore. The conclusions were made on improving the level of information support by preparing subject-specific declarative knowledge and presenting it in an easily accessible form for perception when making decisions on maneuvering. The developed methodology is implemented in the training process of pilots in the training complex of Kerch State Maritime Technological University.
\end{abstract}

Key words: multifunctional simulation, information, ship, development, navigation.

For citation: Dorovskoy V. A., Degtyrev A. V., Smetuch N. P., Zinchenko A. A. Multifunctional simulator for providing ship with data on maneuverability. Vestnik of Astrakhan State Technical University. Series: Marine Engineering and Technologies. 2021;3:14-22. (In Russ.) DOI: 10.24143/2073-1574-2021-3-14-22.

\section{Introduction}

Due to the lack of a methodology for planning an algorithm for the ship maneuvering control system, there is no concept of solving technological problems, and no understanding of what data are needed to perform the task. Therefore, even if the cybernetic devices and programs can perform separate part of the work on preparing the needed data, the navigator does not understand how the device generates them. The goal of the experiments was to build a simulator that will provide data on the ship maneuverability. While training it is necessary and sufficient to create a starting skill at the very beginning, which in practice could be translated into a certain passive skill, when the conditions for navigating are resumed.

\section{Research results}

For developing the initial skills of maneuvering among senior cadets it is necessary to know how to take into account the maneuvering characteristics when forming a given control algorithm. Then comes understanding of what characteristics are needed to ensure the safety of the vessel.

The first step in manually planning a turn is to develop the skill of constructing a curvilinear trajectory of a turn, as given in Appendix IV. Performing the trajectory around the bend provides understanding of how to use the handling performance data and what information is needed. To obtain such data, an algorithm for calculating the characteristics of turn ability was developed, shown in Fig. 1 and the corresponding program [1-3]. 

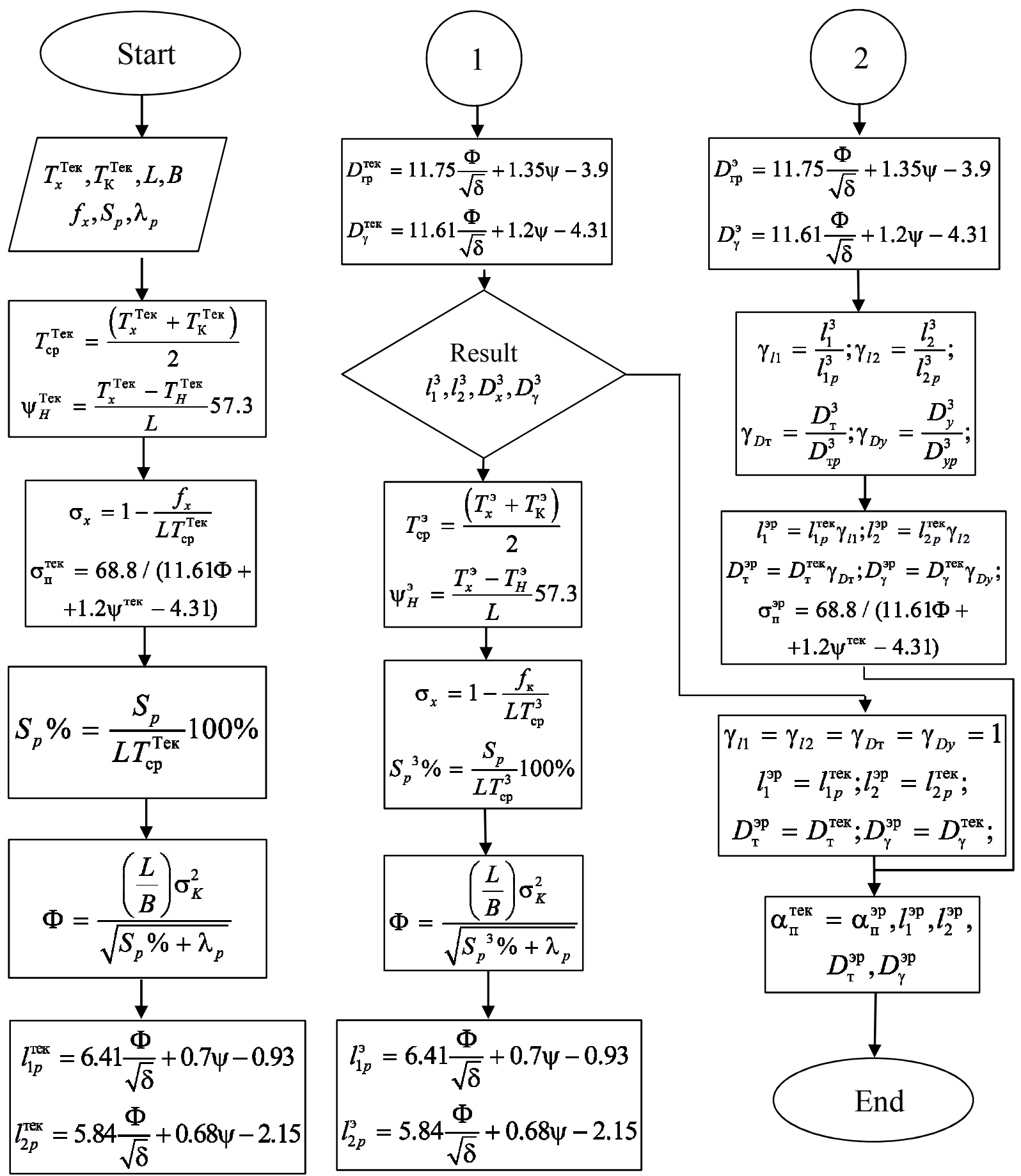

Fig. 1. Step-by-step display of sequential actions for calculating features that describe agility

The most convenient for use in a computer and a compact form of data presentation on the characteristics of turn ability is tabular. The method of accounting for inertial-braking characteristics can be most fully understood when using the inverse method for planning the trajectory of movement when anchored. The described procedure requires knowledge of inertial-braking characteristics and handling characteristics. Building a maneuvering scheme without knowing the specified data is impossible. After understanding the maneuverable characteristics and methods of their use has been reached, the trainees begin to form the initial skills to determine the necessary data. The sequence of further work is shown in Fig. 2. 


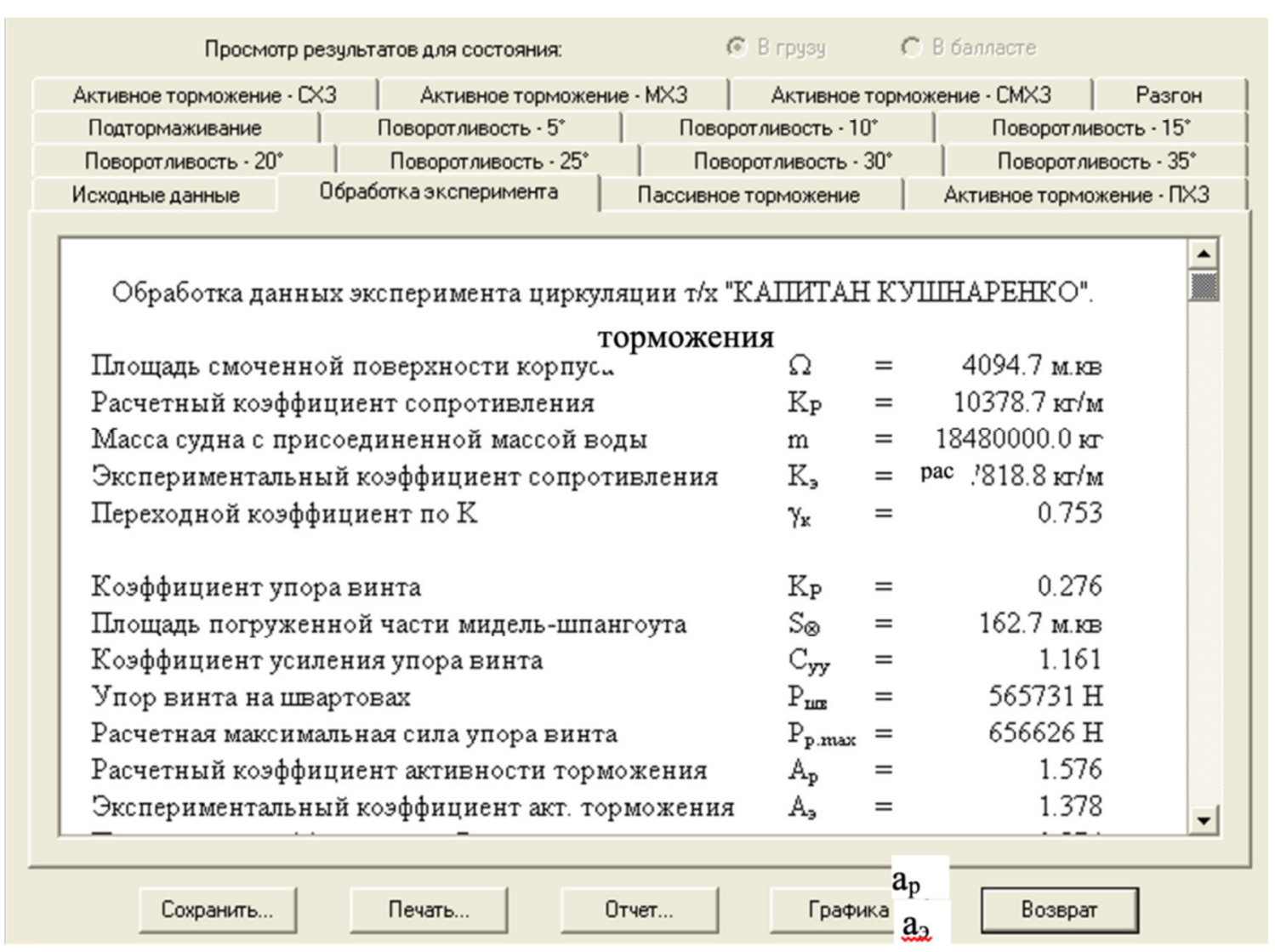

Fig. 2. A fragment of the computer screen at the workshop on calculating maneuverable characteristics

After performing the calculations, the results are presented in the form assigned by the regulatory documents. One of the recommendations is to create them in the folder "Information to the captain about the maneuvering characteristics of the vessel", and this will require a review of the experiment program in the future. The folder must contain the initial data for calculating maneuvering characteristics (Fig. 2):

- tables of circulation characteristics for the state in the load and in the ballast for the rudder angle after 50, with the instability zone;

- turn delay time table, for rudder shift angles after 50;

- the table of the time and angle of rotation for the angles of entry into circulation and return transfer, for the state in the load and in the ballast (V. 1);

- inertial - braking characteristics for the state in the load and in the ballast in the form of IMO line graphs; low water;

- circulation curves for 150 and 350 rudder angles to the right and left for deep water and shal-

- table of coefficients of shallow water influence on circulation;

- inertia-braking characteristics table.

Thus, the educational computer class allows developing practical skills in performing calculations of maneuvering characteristics not only for training purposes, but also for the practical support of real ships, since the accuracy of the experimental calculation method meets the requirements of national and international IMO regulations.

The information to the captain requires a revision of the acceptance test program, which will significantly increase the provision of the maneuvering process [4-6].

As a result of analysis of navigation data that indicated incidents in the North-Western part of the Black Sea, it was found that 43 incidents occurred in the presence of a pilot on Board, and 115, respectively, without a pilot. From this we can conclude that pilotage is an incomparably effective means of improving the safety of navigation. In addition, the captain who works in different parts of the world's oceans is not able to accurately know the local features and conditions of navigation in 
the vast majority of Straits, ports, and channels. The study of the process of information support for pilotage and the development of a skill formation technique were carried out in the water area, the diagram of which is shown in Fig. 3.

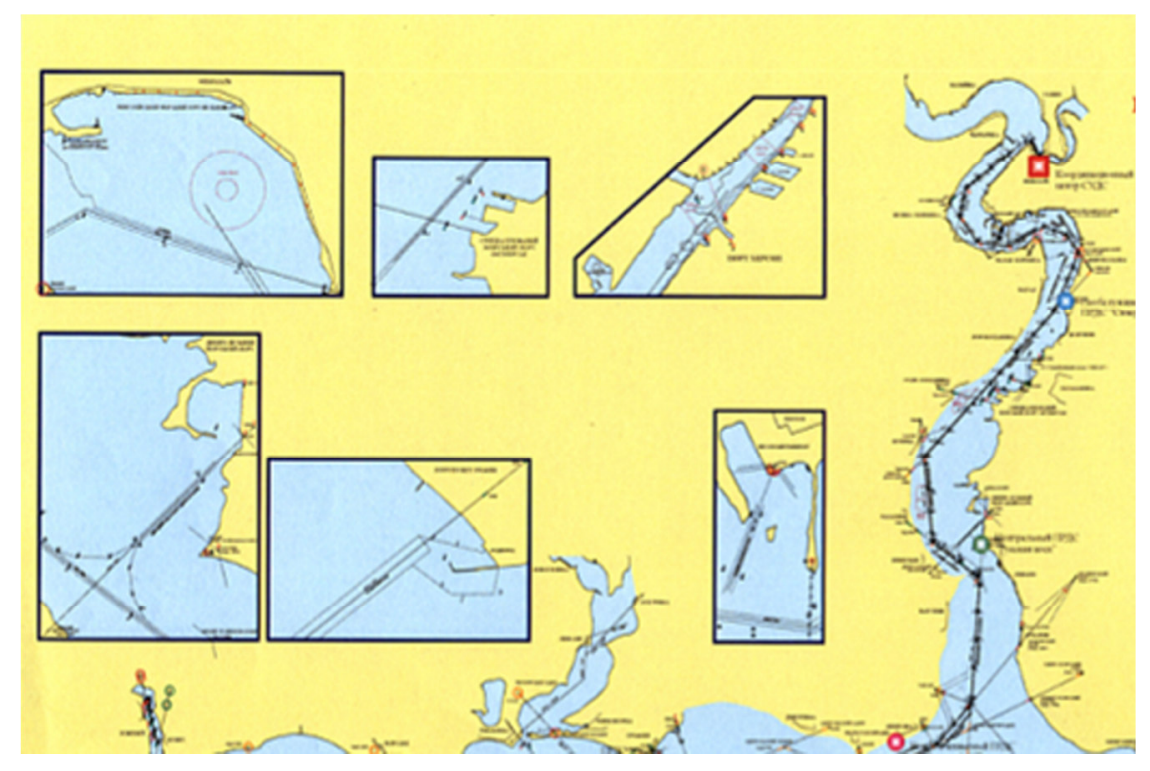

Fig. 3. Western part of the Black Sea

Pilotage, in which any movement of the vessel, anchoring, mooring to the berth or departure from it occurs, have become an obligatory element of traffic control systems in developed countries.

Piloting a ship requires high professionalism of navigation, which can be achieved by special training.

In addition to the experience of working as a captain or captain's mate, a pilot needs special knowledge and his skills should be entirely automatic. For this reason the process of training pilot from a navigator must contain the programs and methods with many essential features. Consideration of these features is important for improving the quality of educational process in maritime educational centers.

However, all known works do not sufficiently reveal the features and stages of the formation of theoretical and practical skills among candidates for a pilot [7-9]. The characteristics of the training system for boatmasters at all levels are not described in sufficient volume, with detail, nor are there any mandatory conditions under which pilots can reach a certain qualification level. In other words, there is no systematic concept of the structure of the complex formation of theoretical and practical skills among the pilot candidates.

The question of whether the methods of training pilots are sufficiently perfect will help to answer the analysis of ways to develop the skill of performing elements of navigational work, presented in Fig. 4. It is not possible for a pilot to develop a stable skill in managing the ship's maneuvers by trial and error. For this reason, it is proposed to form a stable skill in two ways, through the knowledge obtained from the subject knowledge bank; or through the knowledge gained by trial and error on a simulator for maneuvering process control.

Subsequently, a stable skill and a bank of subject knowledge make it possible to bring the control of the maneuvering process to the level of automatic execution of the pilot's intellectual actions.

To ensure the formation of skills among pilots to control the process of maneuvering the vessel, a methodology of preliminary pre-trip training on a simulator using the mathematical model (MM) of a real navigated vessel and adapted to the navigation conditions of the area of upcoming pilotage has been developed. It includes a method of preliminary forecasting of the trajectory of movement and a conceptual model of information support; and also a method of simulator training, consisting of a hardware - software complex of training navigation bridges and simulation model (PRD). 


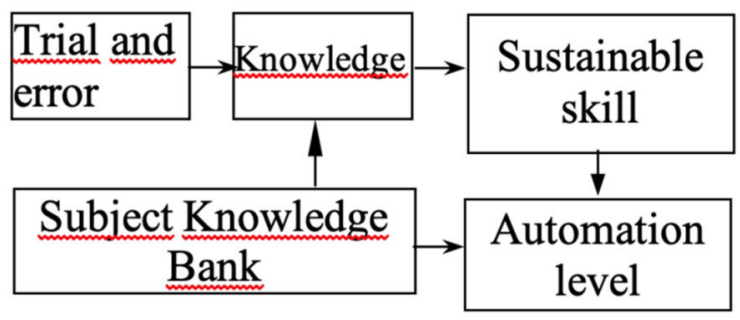

Fig. 4. Ways of forming a pilot's skill

To predict the movement of the vessel, a complex of formalized model algorithms developed by the author is used to obtain the necessary declarative knowledge to prepare a method for controlling the maneuvering process corresponding to the navigation conditions. In addition to performing navigation calculations, the programs allow calculating the inertial and braking characteristics, including the calculation of transition factors [8-10].

The complex includes the following programs:

1. Software for calculating the drift angle ANDRIF, which helps to find out the displacement of a ship under the influence of an imaginary wind;

2. A program for determining the speed and heading angle of true wind ANSTR, which provides the necessary data for calculating the moment of control loss;

3. A program for determining the speed and heading angle of apparent wind TRUWI providing the data to calculate the angle of wind drift during maneuvering;

4. A program for determining the angle of drift from the current ANCUR to determine the displacement on the trajectory when maneuvering;

5. A program for calculating the transition coefficients KORP designed to determine the transition coefficients for resistance, stop and turnability;

6. A program for determining the parameters of turnability TURN designed to obtain values $\ell_{1}, \ell_{2}, D_{\text {т }}, D_{y}$;

7. A program providing the geographic coordinates of the curvilinear trajectory PATURN by the parameters of circulation and the geographic coordinates of the point of intersection of the courses before and after the turn;

8. A program for determining the geographic coordinates of the curvilinear trajectory WICUR by the parameters of circulation, the geographic coordinates of the point of intersection of the courses before and after the turn, and the parameters of wind and current;

9. A program for determining the characteristics of braking WASTO, which allows obtaining the value of the distance and time of braking at different initial speeds and braking modes.

As an example, the results of a braking maneuver in the sea with visualization of the results of maneuvering are shown in Fig. 5.

The teaching methodology using the hardware and software complex provides the three ways of skill formation:

- preparing a manual maneuvering plan to form the skill of analyzing the dynamic characteristics by conducting a business game;

- drawing up a pilotage plan for the area where the vessel is navigated, and a pilot's passport for the area of the forthcoming movement;

- simulator pre-trip training of a pilot on the hardware-software complex for real hydrometeorological conditions of navigation on the ship's MM, which is to be carried out.

The method of forming the skill for analyzing the maneuvering characteristics provides a business game for planning a turn, anchoring, mooring to the berth and maneuvering in case of excessive approach.

To conduct a business game, the data on inertial-braking characteristics are used in the form of a table, a table of data on turnability characteristics in the form of segments, a table of coefficients of shallow water influence on circulation parameters. To plan a turn, the graphical track line should be used before and after the turn. After the skill of building a curvilinear trajectory has been formed, the trainees begin to learn the technique of constructing a trajectory using braking characteristics. This can be most clearly demonstrated by the example of constructing a trajectory when anchored. 


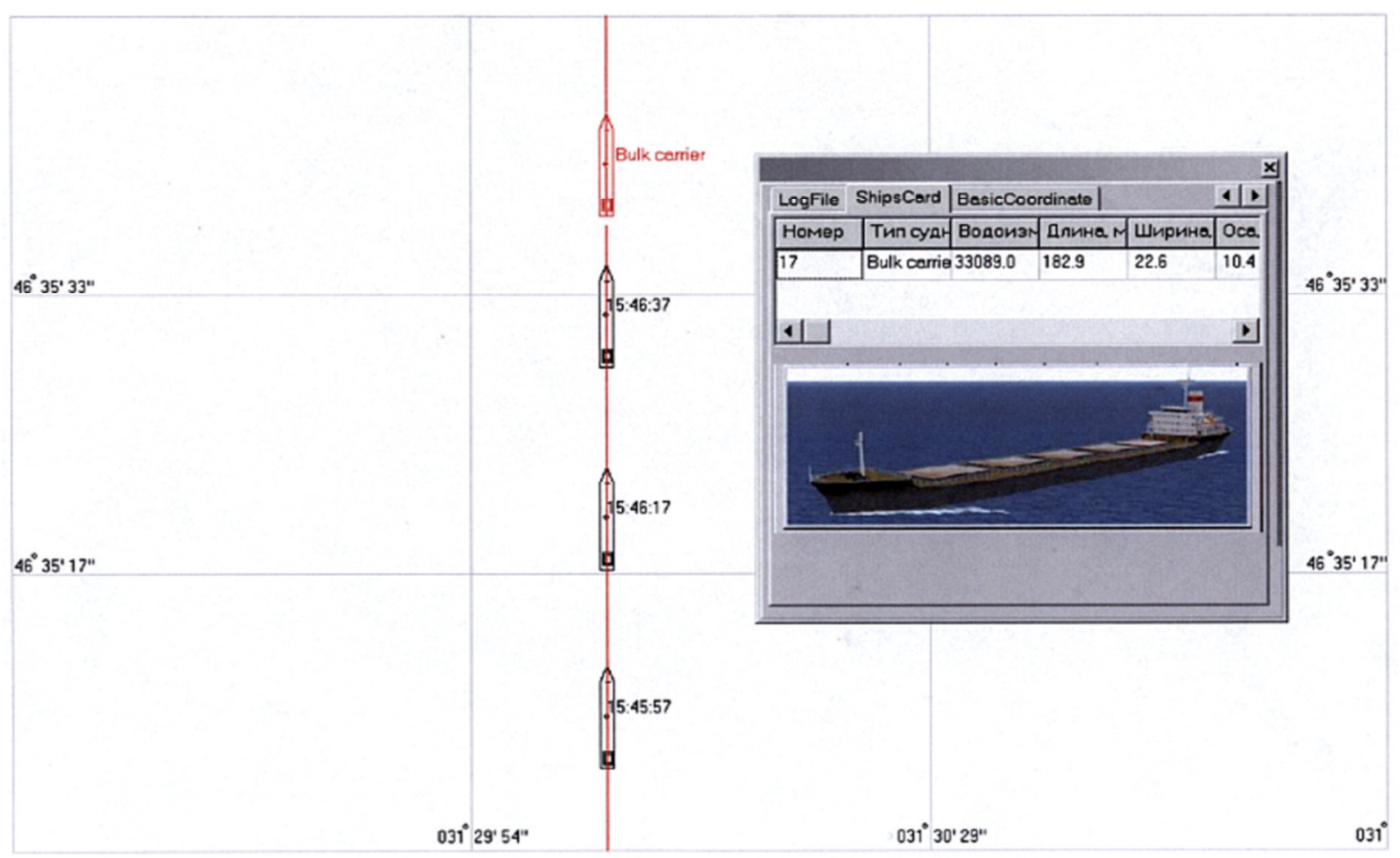

Fig. 5. A fragment of the screen of the hardware and software complex at braking

These two types of maneuvering are enough to understand the methodology for taking into account the properties of the vessel when predicting the trajectory of movement. Building a trajectory when mooring to the berth and in case of excessive proximity allows to consolidate the skill of planning movement and work out tasks on the simulator. All information that circulates through the communication channels can be divided into organizational - administrative and navigation. Navigation information is the priority. Since it is necessary to reduce the level of stress in the work of the operator who controls the maneuvering process, there must be a boatmaster whose duties will include ensuring the safety of communication channels. To improve information support and safety of pilotage, a collision avoidance device was proposed, which must be placed in the visual training system (VTS).

The specified device and system allow to control the movement of ships in the coastal navigation area, including the development of recommendations for divergence.

In the course of developing the information support model two new types of knowledge were introduced: the pilot's passport of the pilotage area and the pilotage plan of the pilotage process.

The pilot's passport of the pilotage area is navigational information adapted to the time of navigation and information about the parameters of hydrometeorological conditions of navigation with the application of data on the traffic pattern. It greatly facilitates the pilot's orientation when navigating and quickly obtaining the necessary information. The pilotage plan of the pilotage process contains, in addition to the specified information, organizational and administrative information on maneuvering with the application of characteristic points at which the mode of movement changes, work with tugs and other intellectual actions is performed.

The methodology of pre-cruise pilot training consists in mastering the techniques on the simulator and developing the skills to control the ship to be piloted in real hydrometeorological conditions.

The considered methodology for developing skills in maneuvering allows to create the preconditions for ensuring safety of navigation during pilotage.

\section{Conclusions}

The created hardware and software complex makes it possible to implement the concept of guaranteed safety of maneuvering process control during pilotage by means of:

- improving the methods of forming a sustainable skill and bringing it to entirely automatic using a subject knowledge bank and a simulator with visualization; 
- introduction of new algorithms for control over the process of vessel movement in the area of responsibility by coastal aids to navigation and development of recommendations for discrepancy;

- increasing the level of information support by preparing subject declarative knowledge and presenting it in an easily accessible form for perception when making decisions on maneuvering;

- new methods of preparing a pilot for the process of pilotage ashore prior to its implementation.

The developed methodology was introduced into the educational process of training pilots in the educational - training complex of the Kerch State Maritime Technological University.

\section{REFERENCES}

1. Novikov V. Analysis of accidents of ships. Shipping, 2000, no. 9, pp. 12-19.

2. Chernyi S. G., Dorovskoi V. A. Metody i sredstva otsenivaniia introspektivnogo monitoringa [Methods and tools for assessing introspective monitoring]. Problemy bezopasnosti i chrezvychainykh situatsii, 2020, no. 1, pp. 75-87.

3. Zhilenkov A. A., Chernyi S. G. Primenenie tekhnologii iskusstvennogo intellekta v avtomatizatsii kontrolia i upravleniia $\mathrm{v}$ sistemakh aktivnykh fazirovannykh reshetok dlia geoinformatsionnogo kompleksa [Using artificial intelligence in automation of control and management in active phased array systems for geoinformation complex]. Oboronnyi kompleks - nauchno-tekhnicheskomu progressu Rossii, 2020, no. 2 (146), pp. 57-63.

4. Maltsev A. S., Romanov G. S., Goncharov E. I., Vilsky G. B. Preparation of pilots to manage ship maneuvers. Navigation. ONMA, 2004, iss. 8, pp. 63-76.

5. Yudovich A. B. Predotvrashchenie navigatsionnykh avarii morskikh sudov [Prevention of navigation accidents of sea vessels]. Moscow, Transport Publ., 1998. 235 p.

6. Golikov V. A. Improving the efficiency and optimization of operating modes of ship microclimate systems: diss ... doc. tech. sci. Odessa, 2000. 408 p.

7. Chernyi S. G., Dorovskoi V. A., Novak B. P. Kontseptsiia postroeniia informatsionnoi podsistemy ASU promyshlennym proizvodstvom [Concept of building ACS information subsystem by industrial production]. Nauchno-tekhnicheskaia informatsiia. Seriia 2: Informatsionnye protsessy i sistemy, 2020, no. 8, pp. 20-23.

8. Chernyi S. G., Avdeev B. A., Vyngra A. V. Razrabotka imitatsionnoi modeli asinkhronnogo elektroprivoda s primeneniem vektornogo upravleniia, kak komponenta strukturnogo programmnogo modulia [Developing simulation model of asynchronous electric drive using vector control as component of structural software module]. Informatsionnye tekhnologii i vychislitel'nye sistemy, 2020, no. 2, pp. 75-84.

9. Bezdolny V. V., Romanov G. S., Goncharov E. I., Vilsky G. B., Maltsev A. S. Method of training pilots: Declarative patent of Ukraine No. 3522 for a utility model; 02.04.2004.

10. Maltsev A. S., Golikova V. V. The dynamics of psychophysiological functions of cadets and navigators when solving navigation problems on a radar simulator. Actual problems of transport medicine, 2007, iss. 1 (7), pp. 20-26.

The article submitted to the editors 17.03.2021

\section{INFORMATION ABOUT THE AUTHORS}

Vladimir A. Dorovskoy - Doctor of Technical Sciences, Professor; Professor of the Department of Electrical Equipment for Ships and Production Automation; Kerch State Maritime Technological University; Russia, 298309, Kerch; esiap@mail.ru.

Andrey V. Degtyrev - Leading Captain of the Company GMZ Ship Management CO SA; Lebanon, BP 185, Beirut; captainandreydegtyarev@gmail.com.

Nadezhda P. Smetuch - Candidate of Technical Sciences; Assistant Professor of the Department of Electrical Equipment for Ships and Production Automation; Kerch State Maritime Technological University; Russia, 298309, Kerch; nadya.s.2011@yandex.ru.

Anton A. Zinchenko - Postgraduate Student of the Department of Electrical Equipment for Ships and Production Automation; Kerch State Maritime Technological University; Russia, 298309, Kerch; zinchenko@kgmtu.ru.

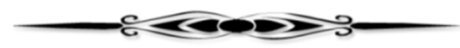




\title{
МНОГОФУНКЦИОНАЛЬНЫЙ СИМУЛЯТОР ДЛЯ ОБЕСПЕЧЕНИЯ СУДНА ДАННЫМИ О МАНЕВРЕННЫХ ХАРАКТЕРИСТИКАХ
}

\author{
В. А. Доровской ${ }^{1}$ А. В. Дегтярев ${ }^{2}$, Н. П. Сметюх ${ }^{1}$ А. А. Зинченко ${ }^{1}$ \\ ${ }^{1}$ Керченский государственный морской технологический университет, \\ Керчь, Российская Федераџия \\ ${ }^{2}$ GMZ Ship Management CO SA, Бейрут, Ливан
}

\begin{abstract}
Проведено исследование в области обеспечения безопасности судна. Отмечено, что в связи с отсутствием методики планирования заданного алгоритма работы системы управления маневрированием не существует единой концепции решения технологических задач, выявлена необходимость выборки и определения данных для выполнения такого рода действий. Несмотря на существующие кибернетические устройства и программы, которые выполняют определенные части работы по подготовке необходимых данных, шкипер не понимает, каким образом устройство их генерирует. Задано создание прототипа, позволяющего получать данные о маневренности судна. После прохождения начального этапа обучения необходимо прививать курсантам умения, которые в процессе практики трансформируются в пассивные и устойчивые навыки. Сформированный программно-технический комплекс позволяет реализовать концепцию гарантированной безопасности управления процессом маневрирования при лоцманской проводке судов за счет совершенствования методов формирования устойчивого навыка и доведения его до уровня автоматизации. Рекомендовано использование тренажера с визуализацией, внедрение новых алгоритмов управления процессом движения судов в зоне ответственности береговой зоны и разработки рекомендаций по дивергенции, новых методов подготовки лоцмана на берегу к процессу плавания судна. Сделаны выводы о повышении уровня информационного обеспечения путем подготовки предметно-декларативных знаний и представления их в доступной для восприятия форме при принятии решений о маневрировании. Разработанная методика внедрена в тренировочный процесс пилотов на учебно-тренировочном комплексе Керченского государственного морского технологического университета.
\end{abstract}

Ключевые слова: многофункциональная симуляция, информация, судно, разработка, навигация.

Для цитирования: Доровской В. А., Дегтярев А. В., Сметюх Н. П., Зинченко А. А. Многофункциональный симулятор для обеспечения судна данными о маневренных характеристиках // Вестник Астраханского государственного технического университета. Серия: Морская техника и технология. 2021. № 3. C. 14-22. DOI: 10.24143/2073-1574-2021-3-14-22.

\section{СПИСОК ЛИТЕРАТУРЫ}

1. Новиков А. В. Analysis of accidents of ships // Shipping. 2000. N. 9. P. 12-19.

2. Черный С. Г., Доровской В. А. Методы и средства оценивания интроспективного мониторинга // Проблемы безопасности и чрезвычайных ситуаций. 2020. № 1. С. 75-87.

3. Жиленков А. А., Черный С. Г. Применение технологий искусственного интеллекта в автоматизации контроля и управления в системах активных фазированных решеток для геоинформационного комплекса // Оборонный комплекс - научно-техническому прогрессу России. 2020. № 2 (146). С. 57-63.

4. Maltsev A. S., Romanov G. S., Goncharov E. I., Vilsky G. B. Preparation of pilots to manage ship maneuvers // Navigation. ONMA. 2004. Iss. 8. P. 63-76.

5. Юдович А. Б. Предотвращение навигационных аварий морских судов. М.: Транспорт, 1998. 235 с.

6. Golikov V. A. Improving the efficiency and optimization of operating modes of ship microclimate systems: diss ... doc. tech. sci. Odessa, 2000. 408 p.

7. Черный С. Г., Доровской В. А., Новак Б. П. Концепция построения информационной подсистемы АСУ промышленным производством // Науч.-техн. информ. Сер. 2: Информационные процессы и системы. 2020. № 8. С. 20-23.

8. Черный С. Г., Авдеев Б. А., Вынгра А. В. Разработка имитационной модели асинхронного электропривода с применением векторного управления, как компонента структурного программного модуля // Информ. технологии и вычислит. системы. 2020. № 2. С. 75-84. 
9. Method of training pilots: Declarative patent of Ukraine N. 3522 for a utility model / Bezdolny V. V., Romanov G. S., Goncharov E. I., Vilsky G. B., Maltsev A. S. The priority of 02.04.2004.

10. Maltsev A. S., Golikova $V$. V. The dynamics of psychophysiological functions of cadets and navigators when solving navigation problems on a radar simulator // Actual problems of transport medicine. 2007. Iss. 1 (7). P. 20-26.

\section{ИНФОРМАЦИЯ ОБ АВТОРАХ}

Владимир Алексеевич Доровской - д-р техн. наук, профессор; профессор кафедры электрооборудования судов и автоматизации производства; Керченский государственный морской технологический университет; Россия, 298309, Керчь; esiap@mail.ru.

Андрей Владимирович Дегтярев - ведущий капитан компании «GMZ Ship Management CO SA»; Ливан, BP 185, Бейрут; captainandreydegtyarev@gmail.com.

Надежда Павловна Сметюх - канд. техн. наук; доцент кафедры электрооборудования судов и автоматизации производства; Керченский государственный морской технологический университет; Россия, 298309, Керчь; nadya.s.2011@yandex.ru.

Антон Александрович Зинченко - аспирант кафедры электрооборудования судов и автоматизации производства; Керченский государственный морской технологический университет; Россия, 298309, Керчь; zinchenko@kgmtu.ru. 